Birlesik Dünya Arastırma

BD-CENTER

Innovasyon ve Yayınılık Merkezi

\section{Global Journal of Foreign \\ Language Teaching}

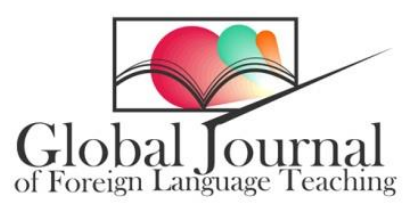

Volume 10, Issue 3, (2020) 182-190

www.gjflt.eu

\title{
The cross-linguistic influence of Arabic on the English passive voice
}

Fatma Lghzeel*, Universiti Malaysia Pahang, 23600 Gambang, Kuantan, Pahang, Malaysia

Noor Raha, Mohd Radzuan, Universiti Malaysia Pahang, 26600 Pekan, Pahang, Malaysia

\section{Suggested Citation:}

Ighzeel, F. \& Raha N. (2020. The cross-linguistic influence of Arabic on the English passive voice. Global Journal of Foreign Language Teaching. 10(3), 182-190. https://doi.org/10.18844/giflt.v10i3.4941

Received from April 10, 2020; revised from June 08, 2020; accepted from August 14, 2020.

Selection and peer review under responsibility of Assoc Prof Dr. Ali Rahimi, Bangkok University, Thailand.

${ }^{\circledR} 2020$ Birlesik Dunya Yenilik Arastirma ve Yayincilik Merkezi. All rights reserved.

\begin{abstract}
It is difficult to describe cross-linguistic influence; however, it has been a contentious phenomenon for a long time. Whenever the speaker of a language becomes bilingual, the first language will subtly affect the new one, even if it is not used much. This is how first language influence begins since the majority of Arab English as a foreign language (EFL) learners suffer from this problem. This current research aims to study the negative influence of the native language (Arabic) on utilising the English passive voice. In this article, we aim to discover the levels of Arab EFL learners' knowledge of the passive voice, as well as to examine the percentage of interlingual and intralingual errors. This study applies a quantitative method. Forty-six participants, who are Arab EFL learners studying at the Universiti Malaysia Pahang, engaged in the task of answering a grammar test. To conclude, the results show that Arab students have a high rate of L1 transfer on the English passive voice, and their levels of knowledge of passive voice are identified. The researchers recommend mixed methods for further research in order to provide a wider understanding about this issue.
\end{abstract}

Keywords: English as a foreign language, mother tongue, native language, target language.

* ADDRESS FOR CORRESPONDENCE: Fatma Ighzeel, Universiti Malaysia Pahang, 23600 Gambang, Kuantan, Pahang, Malaysia.

E-mail address: fatmalghzeel@gmail.com 
Ighzeel, F. \& Raha N. (2020. The cross-linguistic influence of Arabic on the English passive voice. Global Journal of Foreign Language Teaching. 10(3), 182-190. https://doi.org/10.18844/gjflt.v10i3.4941

\section{Introduction}

Grammar is one of the aspects of the English language that contributes successfully to conveying meaning among speakers. Sultana $(2017$, p. 3) defines it, 'As the system of language for altering the structure of words and combines them into language'. It is one of the essential tools that learners need for successful communication with other different language users.

In order to succeed in communication, which is the purpose of acquiring language, speakers of the language must have grammatical knowledge in addition to other skills (Alasfour, 2018). Learners with a very limited amount of grammatical knowledge may be prevented from filling certain social positions (Adger, Wolfram \& Christian, 2014). The process of cross-linguistic influence could be in all of the subskills (vocabulary, pronunciation and grammar), but our concern in this article is only on one aspect of grammar: the passive voice. Constructing a passive voice in English differs from that in Arabic. For this reason, Arab English as a foreign language (EFL) learners combine the Arabic passive voice with that in English. Since tenses in Arabic and English are different, the students may have difficulties in forming the English passive voice.

The problem of cross-linguistic influence occurs when the first language badly affects the target language (TL). Some learners undergo this problem and it is regarded as a kind of habit. According to Erarslan and $\mathrm{Hol}$ (2014), the transfer is an automatic process due to habits of the surface structure mother tongue (MT) onto the surface of the TL. They apply the rules of the first language on the TL, which is wrong. As Gao (2013) indicated, when learners come into contact with a foreign language, they may refer back to their MT's rules to replace those difficulties in the TL.

Clearly, this may not work, as not all languages are precisely the same. The difficulties of the Arab students in this study involve committing errors whenever they write in English, especially when they change a statement from active to passive. The reason for this common error is due to the differences between the languages (Arabic and English). It is certain that the differences between the first and second languages inevitably result in transfer and make it difficult for the learners, while the similarities make the learning process easier (Moattarian, 2013a). Due to the distinctions between the languages, the rules of $\mathrm{L} 1$ should not be generalised to those in the TL.

There are several studies conducted on errors of grammatical rules, generally. One study was conducted on Emirati male students who were investigated in terms of their common grammatical errors. The results pointed out that the most of the common grammatical errors were in the passive voice (Mammeri, 2015). Hence, this study is conducted to shed light, specifically, on the issue of the passive voice.

In this study, the influence is examined through the students' assessments of the grammar test. The impact occurs when the EFL learners change sentences from active to passive. They combine the English passive voice and the Arabic passive voice. The English passive voice is used more often compared to the Arabic. Therefore, EFL learners face some difficulty. Another study was conducted by Mohammed and Abdalhussein (2015) on Iraqi students which investigated the grammatical errors in their writings. The results showed that the Iraqi students made various errors in different grammatical categories' tenses, prepositions, articles, morphological errors, verbs and active and passive voice. In addition, it found that some of these errors were generated because of the effect of the grammatical and linguistic system of the participants' MT on their written production of the TL (English language).

The non-written auxiliary verb when we form the Arabic passive voice could also influence Arab EFL learners' production in creating English passive voice sentences (Alasfour, 2018). Passive voice in Arabic is only a process of vowel change, without any change in the word order or addition of any auxiliary verb. In addition, there is no way of mentioning the doer.

The current study aims to discover the levels of Arab EFL learners' knowledge of the passive voice and to examine the percentage of interlingual and intralingual errors made by the Arab EFL learners in the passive voice. This research is limited to students at the Universiti Malaysia Pahang (UMP). It was 
Ighzeel, F. \& Raha N. (2020. The cross-linguistic influence of Arabic on the English passive voice. Global Journal of Foreign Language Teaching. 10(3), 182-190. https://doi.org/10.18844/gjflt.v10i3.4941

conducted with Arab EFL learners who are students at the university, including male and female participants. The research findings are not generalised to other EFL learners in different countries, for it is limited to the Arab students of the UMP.

\subsection{Error analysis}

Error analysis is one of the most compelling theories in second language acquisition (SLA). It studies the kinds of errors which are made by learners. As AbiSamara mentioned (2003, p.4), error analysis can be viewed as 'a type of linguistic analysis that focuses on errors committed by learners.'

According to Omidipour (2014), it can be concluded that error analysis is based on three very important assumptions, as follows:

1. As we cannot learn a language (either to first or second language) without making errors, errors are unavoidable.

2. Errors are significant in different ways.

3. Not all of the errors result from the learners' MT; i.e. first language transfer is not the only source of errors.

Errors, in general, are normal as a result of the learning process. Also, they are beneficial for both the students and the teachers. Errors provide favourable information for a number of reasons: they provide teachers with feedback about the students' progress; for researchers, it gives evidence as to how the learners are acquiring a language; for learners, it gives various resources in order to learn (Sawalmeh, 2013). Ridha (2012) examined samples of English writing from $80 \mathrm{EFL}$ college students and, then, classified the kinds of errors according to aspects such as lexical/semantic, grammatical, mechanics and word order. The results pointed out that most of the students' errors were due to the influence of their L1. Moreover, Ridha found that the majority of the learners relied on their first language when talking about their opinions. They sometimes translated word-for-word when they expressed their feelings or views in English.

Heydari and Bagheri (2012) defined two types of errors: interlingual errors, which are affected by the MT and which interfere with the learning of the TL and intralingual errors, which are caused by the TL.

\subsection{Interlingual and intralingual errors}

Interlingual and intralingual errors are produced differently. Interlingual errors are 'caused by mother tongue interference' (Falhasiri, Tavakoli, Hasiri \& Mohammadzadeh, 2011, p. 39), while intralingual and developmental errors happen during the learning process of the second language at a stage when the learners have not really learned sufficient knowledge (Falhasiri et al., 2011). These two kinds of errors are very similar and cause confusion at times.

The commencement of the learning process is marked by errors due to the MT; however, during the learning process, intralingual transfer appears at every step. It has been discovered that the first stages of language learning are characterised by a preponderance of transfer (interlingual interference), which is caused by learner's MT; however, when the learner starts to acquire parts of the new language, the intralingual transfer is demonstrated gradually (Yu, 2013).

It is easy to see that EFL errors are caused by translation (word-for-word) or thinking in the first language. As Brudiprabha (1972) claimed, one-third of errors occur because of the negative transfer of L1. Furthermore, since the EFL learners rely on their native language (NL) when they write, it could be seen, obviously, that interlingual errors are mostly found in EFL learners' compositions (Kaweera, 2013). The rate of errors is highly increased in the TL, as there are differences between L1 and L2. 
Ighzeel, F. \& Raha N. (2020. The cross-linguistic influence of Arabic on the English passive voice. Global Journal of Foreign Language Teaching. 10(3), 182-190. https://doi.org/10.18844/gjflt.v10i3.4941

\subsection{Language transfer}

Language transfer has been a contentious issue in SLA for a long time. It is another term for influence; so it refers to the process of using knowledge of the first language (L1) in learning the second language (L2). Language transfer may occur in two situations: positive transfer, which does not influence the learning of the TL and negative transfer, whereby the learner's $L 1$ is one of the sources of the errors. The terms transfer and cross-linguistic influence are used interchangeably in this study to refer to the same topic.

Dulay, Burt and Krashen (1982) argued that acquiring L2 does not work the same way as acquiring L1. Even though the errors of L2 learners are very similar to those of L1 learner, they are mostly developed and not transfer errors (Karim \& Nassaji, 2013). However, L1 and L2 errors are similar; they are called developmental errors, not transfer errors.

Moreover, Karim and Nassaji (2013) examined the literature on transfer studies and concluded that L1 transfer is effective in L2 learning as writing and creating a strategy that helps learners develop, write and organise their ideas and generate it in L2. Furthermore, Torrijos (2009) studied the impact of $\mathrm{CLI}$ in SLA. The researcher summarised that, in addition to language combining literary skills in L1, social factors, individual differences, etc. (Moattarian, 2013a). Thus, L1 interference plays a very vital role in SLA, the importance of which extends to students, researchers and teachers.

In addition, Banjar (2014) claimed that it is worth mentioning that distinctive factors influence the amount and kind of the transfer during the process of SLA. The first factor is the age of the learner. It is believed that children are less affected by transfer than adults because their MT language is not strongly influenced. The level of language ability of the learner is also another factor. It has been proved that there is more syntactic transfer at the beginning level of language acquisition than at the more advanced levels. As most of the learners do not know much about the second language at the beginning stages of language acquisition, they tend to depend on the grammatical rule of their NL.

\subsection{English passive voice}

The passive voice is used to reduce the important role of the doer and is formed with auxiliary 'be' and the past participle of the main verb. Constructing a passive voice sentence can be either long or short by mentioning the doer of the action (by phrase) or by deleting it from the sentence (Bailey, 2016). For instance, the active sentence, 'the student wrote the assignment,' becomes short and passive, 'the assignment was written', or long and passive, 'the assignment was written by the student.'

There is a distinction which is related to the verbal/adjectival passive and to the distinctions in aspectual meaning. The difference is whether the verbs are dynamic or static verbs (Pullum, 2014). The main distinction between English and Arabic languages is that auxiliary verbs exist in English but they do not in Arabic. As Al-Sindy (1995) claimed, using auxiliary and copula cause difficulties for learners whose MT is Arabic and who are learning English as a foreign language. Arabic sentences do not contain a copula in the simple present passive voice. Therefore, an Arab learner, when generating English sentences, is likely to omit copula; that is, Arabic sentences consist of the subject and a complement, while some English sentences consist of the subject, the copula, and a complement. For instance, an English sentence: The student is intelligent; an Arabic sentence: The student intelligent.

\subsection{Arabic passive voice}

Arabic is a Semitic language whose verbal system is variable and rich morphologically. The Arabic language is spoken by more than $\mathbf{4 2 2}$ million speakers around the world. In addition, it is also spoken as a first language (L1) in most of the Arab countries such as Iraq, Kuwait, Saudi Arabia, Syria, Jordan, UAE, Oman, Yemen, Lebanon, Bahrain, Qatar, Israel and Palestine. 
The Arabic language is also considered as the L1 in the Arab countries of Africa: Libya, Tunisia, Sudan, Algeria, Somalia, Morocco, Mauritania, Egypt and Djibouti. Since natives speak Arabic as their L1, the aforementioned countries are indicated as the Arab world. In specific countries of Asia and Africa, Arabic is considered and used as a second language. These certain countries include Indonesia, India, Pakistan, Iran, Nigeria and Chad (Alshayban, 2012).

There are differences in both the sounds and the systems of writing in Arabic and English. Because Arabic is always written from right to left, Arabic books are formed with their spines on the right side. The passive voice in Arabic has not yet been learned as extensively as in English. The grammarians of Arabic sometimes mention the forms of passive verbs in Arabic and, in brief, outline the texts in which the passive is utilised (Aws Nabeel, 2017).

Passives in Arabic are less common than they are in English. The passivation in Arabic consists of changing the vowel of the verb, while keeping the word order and without mentioning the agent at all; for example, 'the assignment written'. Unlike the English passive, it is optional, as you can decide whether or not to mention it.

The object in the active sentence becomes the subject in the passive sentence. The distinction in Arabic is that we do not mention the doer of the action, while in the English passive we do. The subject of the passive is the object of the active verb and it is noticed as a nominative case in the classical/standard Arabic variety. The verb changes into the passive by changing the vowels of the main verb and tense prefix or by adding a prefix (Al-Raba'a, 2013).

The role of the MT or L1 has been a much debated subject in second language learning. Arab EFL learners are affected by their MT's (Arabic) interference when they come in contact with the TL (English).

Therefore, Sebastian (2019) added that most teachers believe that the use of the L1 has to be reduced and they feel guilty if they use it too often. When they are challenged, they find it complex to give the reason. Regardless of the use of the L1, it is generally assumed that English has to be learned by using English in the same way in which you learn the MT by using the MT, although Patrick, Sui, Didan and Gyang (2013) argued that the MT has a significant importance to the educational foundation of the learners. The Nigerian National Policy on Education stated that from pre-primary to the first three years of primary education, the MT or the L1 must be the medium of communication or language of the immediate environment. This is because the experience of background is required to make the learning process conducive for all learners.

\section{Methodology}

Quantitative methods are used in this study. This section focuses on the research design and provides descriptions of the participants involved, the instruments and the procedures performed in the study. One research tool was employed, which was a grammar test, as well as the processes involved, which are detailed in the sub-sections below.

\subsection{The participants}

The study was conducted in the UMP. The participants of the research were Arab EFL learners who were UMP undergraduates. They were 46 students who were learning English as a foreign language. The students were from two Bahasa Melayu classes, and they were specialising in different fields such as computer science, software engineering and chemical engineering. The participants were from various Arab countries, namely Egypt, Saudi Arabia, Yemen, Libya, and Iraq. Their ages ranged between 23 and 25 years. 


\subsection{Research tool}

In the current study, a grammar test was the material that was used to gather data about the crosslinguistic influence of Arabic on the English passive voice. The grammar test was created to cope with all levels of students' knowledge. Swan and Walter (2011) were graded at B1 and B2. Yule (2015) was graded at C1 and C2, while the grammar book of Paterson (2009) was graded at B.

The grammar test consisted of three exercises: the first one asked the participants to fill in the blanks; for example: 'When I arrived in the Dream Country I (1 take) straight to the palace.' Here the students were required to put a suitable auxiliary verb with a suitable tense and to put the main verb in the past participle.

The second exercise asked the students to change the active sentences into passive sentences. For instance: 'You should take these pills with food and avoid carbonated drinks.'

The last one was the multiple-choice section where the students selected the correct passive voice structure. For instance:

- This ice cream has a very unusual taste.

A. I think someone makes it with coconut milk.

B. I think it is made with coconut milk.

The researchers conducted the test to gather data concerning the students' errors and to ascertain an authentic proportion of the students who made errors.

\section{Data analysis}

Data analysis is a process which consists of techniques utilised by researchers to answer the research questions of the study. According to Teddlie and Tashakkori (2009), the focus of the quantitative study is to gather numerical data and generalise it across groups of people. Data, which were obtained from grammar test, were analysed manually so that the errors were counted and after that the percentages were calculated.

\section{Findings and discussion}

\subsection{The levels of the students' knowledge}

The findings of the current study revealed that Arab EFL learners encountered many challenges with the English passive voice. The test papers of the students were marked to find their levels in the passive voice. The total number of students who were at the beginner level was 40 , whereas only 1 student was at an advanced level. The beginner level ranged between $1 \%$ and $49 \%$, and the intermediate level ranged between $50 \%$ and $74 \%$. Moreover, the high intermediate level consisted of students who scored between $75 \%$ and $87 \%$, whereas students who scored $88 \%$ and above could be placed in the advanced level. These levels of knowledge were designed according to Liao (2010).

There were only five students at the intermediate level and no one at a high intermediate level. Based on this, the highest number of students were beginners having low marks in the grammar test.

Table 1. Levels of students' knowledge of the passive voice

\begin{tabular}{lllll}
\hline & Beginner & Intermediate & High intermediate & Advanced \\
\hline 40 & 5 & 0 & 1 & \\
\hline
\end{tabular}

With reference to Table 1, it is evident that most of the Arab students were at a beginner level, so the majority had very limited knowledge about the English passive voice. A similar study was 
conducted by Al-Zoubi and Abu-Eid (2014) on the interference of Arabic in learning English. The results found that the students committed more transfer errors with verbs such as 'to be' and passive voice more than other types of errors.

In addition, it has been noticed in the current study that some of the students avoided using the passive voice in that they were just writing the sentences as it was (active voice). Furthermore, the majority of the participants committed errors when they did not write the auxiliary verb when they constructed passive sentences. This result was in harmony with that of Abbas, Younus and Khalil (2019), in which students did not usually write the auxiliary verb or the verb 'to be', which proceeded the past participle verb. They added that they were not familiar with the use of the auxiliary or copula in the English passive voice since they do not have an equivalent in their NL.

\subsection{The percentages of interlingual errors and intralingual errors}

One of the aims of this study was to identify the percentages of interlingual and intralingual errors, which were calculated manually. The analysis was done by examining each error in every question in both exercises (first and second exercise). The kind of error was identified by the researchers; they then counted the errors and calculated the percentage of interlingual and intralingual errors. Examples of interlingual errors are as follows: '*told', instead of 'was told', '*Peter called a fool by many people', instead of 'Peter was called a fool by many people.' Examples of intralingual errors are as follows: '*was expected', instead of 'had been expected.' '*smaller fish are always chased, caught and eaten by big fish', instead of 'smaller fish are always being chased, caught and eaten by big fish.'

Table 2. The proportion of interlingual errors and intralingual errors

\begin{tabular}{lcc}
\hline \multicolumn{1}{c}{ Type of error } & Exercise 1 & Exercise 2 \\
\hline Interlingual & $89.1 \%$ & $95.6 \%$ \\
Intralingual & $67.3 \%$ & $52.1 \%$ \\
\hline
\end{tabular}

As noted in Table 2, the highest percentage in Exercise 1 was interlingual errors, which was 89.1\%, while the intralingual percentage was $67.3 \%$. For Exercise 2, the interlingual errors had the highest percentage compared to intralingual errors (95.6\% and $52.1 \%$, respectively). Based on Table 2, students' errors were considered to be caused by interlingual more than intralingual factors. Most of the students' errors were a consequence of the transfer of Arabic; thus, this influence caused problems forming the English passive voice in sentences. In a similar study, Moattarian (2013b) concluded that participants were unable to differentiate in their L2 between L1 and L2 rules. As a result, they generated a large amount of L1 transfers. Similar to the current study, the participants applied the same standards of their MT on the TL in constructing passive voice sentences, which was considered the wrong strategy. According to Mourssi (2013) study, which investigated the crosslinguistic influence of the L1 in learning L2 grammar, aspects in the L1 helped learners with the TL if both languages basically shared the same elements; however, it hindered them when they were different. Furthermore, there was a similar study conducted by Ngangbam (2016), who investigated 60 native Arabic-speaking students. Here, 15 aspects of errors were categorised to find out the causes of syntactic errors, which occurred too often, as well as areas of weaknesses and difficulties that regularly happened in their writing. The findings pointed out that the primary source of committing these syntactic errors in this research was the interference of the first language.

\section{Conclusion and recommendations}

The present study has investigated the phenomenon of cross-linguistic influence that Arab EFL learners undergo on the English passive voice. The data obtained from the grammar test showed that most of the students were beginners and had very limited knowledge of the English passive voice. Moreover, the number of occurrences of interlingual errors surpassed the number of intralingual errors. Therefore, there is a high transfer of the MT (Arabic) on the TL. 
Ighzeel, F. \& Raha N. (2020. The cross-linguistic influence of Arabic on the English passive voice. Global Journal of Foreign Language Teaching. 10(3), 182-190. https://doi.org/10.18844/gjflt.v10i3.4941

The issue of cross-linguistic influence has become debatable and semi-universal. Furthermore, many EFL learners suffer from this problem in many countries around the world. Thus, this research will help a considerable number of students and learners of EFL generally, in all Arab countries.

For further studies, it is recommended that a mixed approach should be used to give a more extensive understanding of not only which strategies are influential, but also the sources of the transfer. More research is required with Arab EFL learners from different backgrounds and various levels of education. It is also recommended that the research should include different exercises and various writing tasks.

\section{Implications of the Research}

Because of the poor knowledge and confusion with the English passive voice, in order to be skilful in constructing English passive voice sentences, students are expected to set a strong foundation of passive voice rules and to identify the distinctions between the learners' NL and the TL in terms of EFL learners of Arabic and English.

The teachers should choose the appropriate method and techniques which focus on the student, for they are the centre of the learning process. Moreover, the university policy should determine using English inside the classroom so gradually students will depend on the TL.

As for Arab EFL learners, teachers have to teach the rules of the English passive voice with more care and highlight the major distinctions between English and Arabic so that students do not rely on their L1. Moreover, in order to make sure students understand the rules, teachers are supposed to offer some examples so that students would participate in the classroom exercises. Once the comprehension of the passive voice can be heightened, the performance of students with the passive voice can be developed.

\section{Acknowledgements}

The authors would like to express our thanks to the UMP as a whole and we are really thankful for the participants and the Bahasa Melayu teachers for helping us with the data collection.

\section{References}

Abbas, N. F., Younus, L. L. \& Khalil, H. H. (2019). Fossilized use of active and passive simple present by Iraqi MA students. Arab World English Journal (AWEJ), 10(1), 16-30.

AbiSamra, N. (2003). An analysis of errors in Arabic speakers' English writings. Investigating writing problems among Palestinian students studying English as a foreign language (Unpublished doctoral dissertation).

Adger, C. T., Wolfram, W. \& Christian, D. (2014). Dialects in schools and communities. Routledge.

Al-Raba'a, B. (2013). The grammatical influence of English on Arabic in the passive voice in translation. International Journal of Linguistics, 5(1), 204-218.

Al-Sindy, H. A. (1995). Analysis of syntactic interference errors in the writing of English by Saudi adult students.

Al-Zoubi, D. M. \& Abu-Eid, M. A. (2014). The influence of the first language (Arabic) on learning English as a second language in Jordanian schools, and its relation to educational policy: Structural errors. Sino-US English Teaching, 11(5), 355-372.

Alasfour, A. S. (2018). Grammatical errors by Arabic ESL students: an investigation of L1 transfer through error analysis.

Alshayban, A. S. (2012). Copula omission by EFL Arab learners. Fort Collins, CO: Colorado State University.

Aws Nabeel, H. (2017). The use of the passive voice in the writing of Arab ESL learners/Aws Nabeel Hameed. Kuala Lumpur, Malaysia: University of Malaya.

Bailey, A. (2016). The effect of extended instruction on passive voice, reduced relative clauses, and modal would in the academic writing of advanced English language learners. 
Ighzeel, F. \& Raha N. (2020. The cross-linguistic influence of Arabic on the English passive voice. Global Journal of Foreign Language Teaching. 10(3), 182-190. https://doi.org/10.18844/gjflt.v10i3.4941

Banjar, H. (2014). Interlanguage idiomatics: the acquisition of English idioms by Saudi learners.

Dulay, H., Burt, M. \& Krashen, S. (1982). 1982: language two. New York: Oxford University Press.

Erarslan, A. \& Hol, D. (2014). Language interference on English: Transfer on the vocabulary, tense and preposition use of freshmen Turkish EFL learners. ELTA Journal, 2(2), 4-22.

Falhasiri, M., Tavakoli, M., Hasiri, F. \& Mohammadzadeh, A. (2011). The effectiveness of explicit and implicit corrective feedback on interlingual and intralingual errors: a case of error analysis of students' compositions. English Language Teaching, 4(3), 251.

Gao, H. (2013). On source language interference in interpretation. Theory \& Practice in Language Studies, 3(7).

Heydari, P. \& Bagheri, M. S. (2012). Error analysis: sources of L2 learners' errors. Theory \& Practice in Language Studies, 2(8).

Karim, K. \& Nassaji, H. (2013). First language transfer in second language writing: an examination of current research. Iranian Journal of Language Teaching Research, 1(1), 117-134.

Kaweera, C. (2013). Writing error: a review of interlingual and intralingual interference in EFL context. English Language Teaching, 6(7), 9-18.

Liao, E.-H. (2010). An investigation of crosslinguistic transfer in EFL learners' phraseology. ERIC.

Mammeri, S. (2015). A morphosyntactic study of EFL students' written compositions: a corpus based analysis. Arab World English Journal.

Moattarian, A. (2013a). Bidirectional crosslinguistic influence in language learning: Linguistic aspects and beyond. International Journal of Linguistics, 5(4), 38-49.

Moattarian, A. (2013b). Bidirectional crosslinguistic influence in language learning: Linguistic aspects and beyond. International Journal of Linguistics, 5(4), 38.

Mohammed, M. S. \& Abdalhussein, H. F. (2015). Grammatical error analysis of Iraqi postgraduate students' academic writing: the case of Iraqi students in UKM. International Journal of Education and Research, 3(6).

Mourssi, A. (2013). Crosslinguistic influence of L1 (Arabic) in acquiring linguistic items of L2 (English): an empirical study in the context of Arab learners of English as undergraduate learners. Theory \& Practice in Language Studies, 3(3).

Ngangbam, H. (2016). An analysis of syntactic errors committed by students of English language class in the written composition of Mutah University: a case study. European Journal of English Language, Linguistics and Literature, 3(1), 1-13.

Omidipour, M. (2014). An analysis of errors in writing among adult Persian learners of English. International Journal of Language Learning and Applied Linguistics World, 5(3), 176-187.

Paterson, K. (2009). Oxford practice grammar basic: with key practice-boost CD-ROM pack. Oxford, UK: Oxford University Press.

Patrick, J. M., Sui, M., Didan, B. \& Gyang, T. (2013). Mother-tongue interference on English language pronunciation of senior primary school pupils in Nigeria: implications for pedagogy. Language in India, 13(8), 281-298.

Pullum, G. K. (2014). Fear and loathing of the English passive. Language \& Communication, 37, 60-74.

Ridha, N. S. A. (2012). The effect of EFL learners' mother tongue on their writings in English: An error analysis study. ADAB AL-BASRAH, (60), 22-45.

Sawalmeh, M. H. M. (2013). Error analysis of written English essays: The case of students of the preparatory year program in Saudi Arabia. English for Specific Purposes World, 40(14), 1-17.

Sebastian, H. (2019). The interference of first language towards English speaking for Chinese college students of the Department of English in the University of Sumatera Utara Medan.

Sultana, M. (2017). The role of grammar teaching in English language learning: a study of the higher secondary level in Bangladesh. Dhaka: Bangladesh: BARC University.

Swan, M. \& Walter, C. (2011). Oxford English grammar course. Oxford, UK: Oxford University Press.

Teddlie, C. \& Tashakkori, A. (2009). Foundations of mixed methods research: integrating quantitative and qualitative approaches in the social and behavioral sciences. Thousand Oaks, CA: Sage.

Yu, Y. (2013). The negative transfer in sentence pattern in Chinese English interlanguage.

Yule, G. (2015). Oxford practice grammar advanced. Oxford, UK: Oxford University Press. 